\title{
VESICULAR ARBUSCULAR MYCORRHIZA INFLUENCES THE HISTO-ANATOMIC CHARACTERISTICS OF VEGETATIVE ORGANS IN ARTEMISIA ANNUA
}

\author{
Erzsébet DOMOKOS $^{1 *}$, Lilla Laura CSŐSZ ${ }^{1}$, Béla DARKÓ ${ }^{1}$, László JAKAB-FARKAS ${ }^{2}$ \\ ${ }^{1}$ Department of Fundamental Pharmaceutical Sciences, Discipline of Pharmaceutical Botany, University of \\ Medicine, Pharmacy, Sciences and Technology of Târgu Mureș, Romania \\ ${ }^{2}$ Department of Electrical Engineering, Sapientia Hungarian \\ University of Transylvania, Cluj-Napoca, Romania
}

*Correspondence:

Erzsébet DOMOKOS

erzsebet.domokos@umfst.ro

Received: 11 May 2019; Accepted: 12 June 2019; Published: 30 June 2019

\begin{abstract}
Recent studies have shown that vesicular-arbuscular mycorrhizae stimulate plant growth in case of Artemisia аппиа plants. According to these studies mycorrhization can enhance plant height and biomasses, shoot branching and inter-nodal length, foliar glandular hair density, and nutrient status of shoots and leafs. Contradictory data were obtained in case of leaf chlorophyll content and photosynthetic rate. The effects of vesicular-arbuscular mycorrhizae on roots, shoots and leafs anatomy of A. annua have not been studied yet. The aim of this paper was to compare the microscopic characteristics of the vegetative organs from the Artemisia аппиа plants treated with vesicular-arbuscular mycorrhizae, with those from the control plants. Rhizophagus irregularis influenced the development of vascular tissues in root and stem of Artemisia plants by increasing their surface in the organs. Mycorrhization also reduced the percentage of lignification in the cortex of the root, increased the percentage of palisade parenchyma in leaf and had a positive effect on foliar glandular hair density. Further investigations are necessary to find out the role of these histo-anatomic alterations in the growth and development of Artemisia plants.
\end{abstract}

Keywords: Rhizophagus irregularis, anatomy, histology, root, stem, leaf, glandular hair.

\section{Introduction}

Recent studies have shown that vesiculararbuscular mycorrhizae stimulate plant growth in case of Artemisia annua (Chaudhary et al., 2007; Kapoor et al., 2007; Awasthi et al., 2011; Huang et al., 2011; Tan et al., 2013; Fortin and Melchert, 2015; Giri, 2017; Domokos et al., 2018). According to these studies mycorrhization can enhance plant height and biomasses, shoot branching and inter-nodal length, foliar glandular hair density, and nutrient status of shoots and leafs.
Contradictory data were obtained in case of leaf chlorophyll content and photosynthetic rate (Kapoor et al., 2007; Huang et al., 2011; Rapparini et al., 2008). The effects of vesicular-arbuscular mycorrhizae on roots, shoots and leafs anatomy of $A$. annua have not been studied. The hypothesis of this work was that vesicular arbuscular mycorrhiza stimulates plant growth by changes in vegetative organ anatomy. Therefore the objective of the study was to compare the microscopic characteristics 
of the vegetative organs from the Artemisia апnиa plants treated with vesicular-arbuscular mycorrhizae, with those from the control plants.

\section{Materials and Methods}

The plants (Artemisia annua Anamed A-3, Winnenden, Germany) were cultivated in 2017 in Corunca (Mureș County, 46³1'18.18' 'N and $24^{\circ} 35^{\prime} 53.78^{\prime}$ 'E) as previously described in Domokos et al. (2018). For comparison of microscopic features of vegetative organs, 20 plants treated with Rhizophagus irregularis and 20 control plants were used. Observations were made on plants harvested in July. Sections of vegetative organs were done by hand microtome and razor. For staining iodine green and ruthenium red was utilized (Tanase et al., 2017). Microscopic images were obtained by a Motic B3 (Hong Kong) optical microscope equipped with a Canon EOS 1100D (Taiwan) camera. Leaf surface of 40 treated plants and 40 control plants was observed with a JEOL JSM-5200 (Japan) scanning electron microscope. Analysis of obtained microscopic images was performed with Image Image Processing and Analysis in Java Version 1.51j8 (National Institute of Mental Health, Bethesda, MD, United States). The data did not have a normal distribution (Shapiro-Wilk test), thus for data comparing the Wilcoxon signed rank test (Past 2.17, Hammer et al., 2001) was used.

\section{Results and discussions}

The cross section of the A. annua root had a circular outline (Fig.1.). The root presented a secondary structure. From the external part of the root to the internal part, the following tissues could be distinguished: periderm (cork) formed by the phellogen, cortex with a few tangentially elongated secretory ducts (Fig. 2), three or more sclerenchyma bundels, secondary phloem (in form of a thin ring surrounding the secondary xylem), secondary xylem which occupies the largest area and fills the pith too. This structure had a lower degree of lignified cells than the plants collected later, in the flowering period, described by Ivănescu et al. (2015).
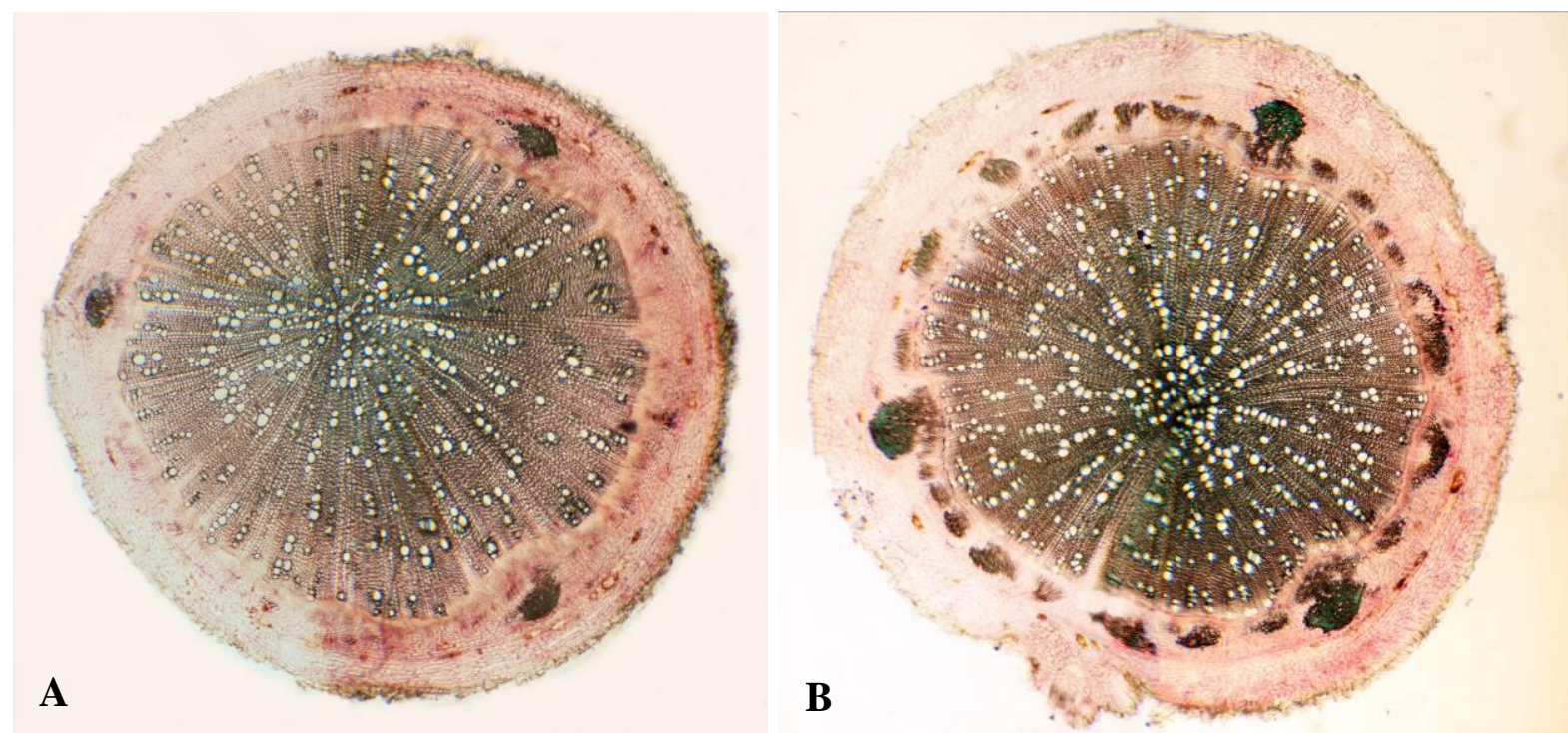

Fig. 1. Artemisia annua roots-general view (4x): A. Plant treated with Rhizophagus irregularis; B. Control plant (Photos: Erzsébet Domokos) 
The cross section of stem (on middle part) was quasi-circular with more than 10 horns (Fig. 3). The stem presented a primary structure. From the external part of the stem to the internal part, the following tissues could be distinguished: epidermis with almost square or rectangular cells covered by cuticle, collenchyma layers under the epidermis, cortex without secretory cavities, collateral vascular bundles arranged in circle, and pith parenchyma (Fig. 4.). Glandular hairs, medifixed hairs, and stomata from the epidermis were less than on the leaf surface. These findings were in accordance with Ivănescu et al. (2015) and Tu (2017).

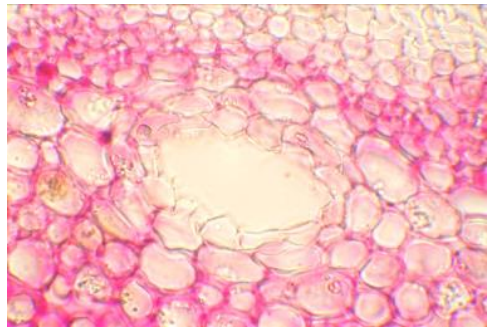

Fig. 2. Secretory duct in the cortex of Artemisia annua root-detail (40x) (Photo: Erzsébet Domokos)
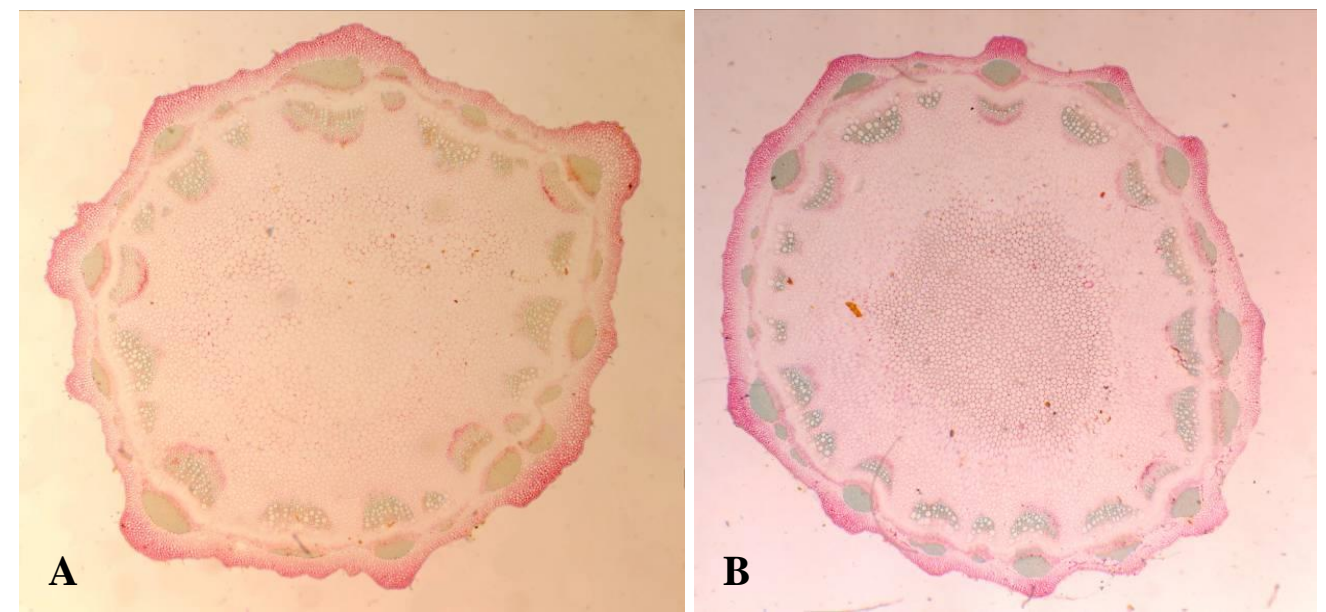

Fig. 3. Artemisia annua stems-general view (4x): A. Plant treated with Rhizophagus irregularis; B-control plant (Photos: Lilla Laura Csősz)

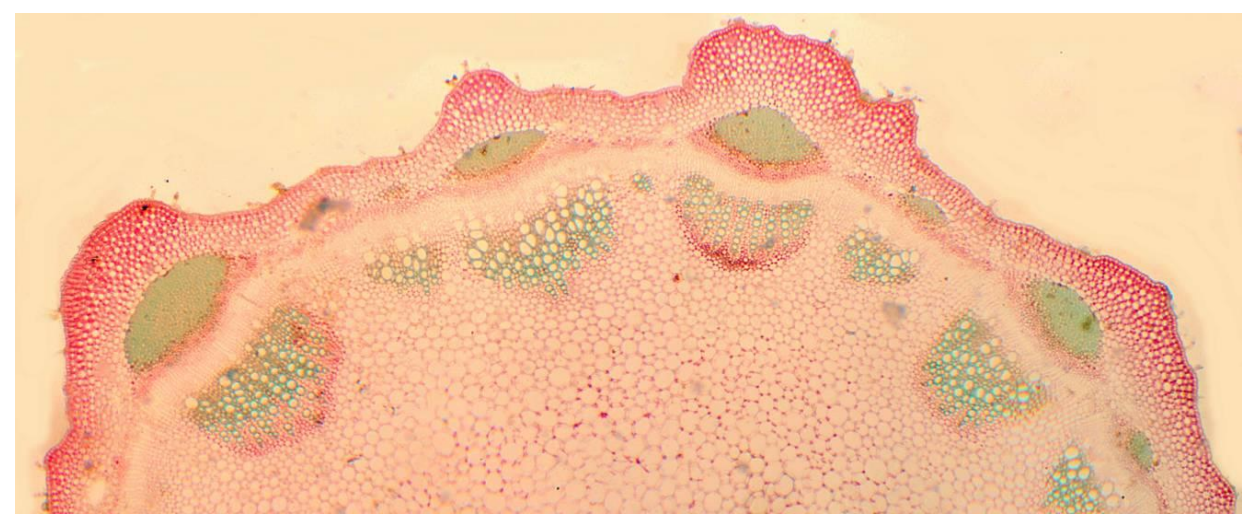

Fig. 4. Artemisia annua stem-detail (4x): epidermis, collenchyma layers, thin cortex, collateral vascular bundles, sclerenchyma cap covering the phloem, band of multi-layered fascicular and interfascicular cambium, pith (Photo: Lilla Laura Csősz) 
The leaf transection (on ultimate lobe) parenchyma trough the midrib arranged in two presented the following structure (Fig. 5.): layers (otherwise in one layer), collateral epidermis with cuticle, glandular hairs, vascular bundle (surrounded by fundamental medifixed hairs and stomata (Fig. 6.), tissue) and lower palisade parenchyma isobilateral mesophyll, upper palisade arranged in one layer.
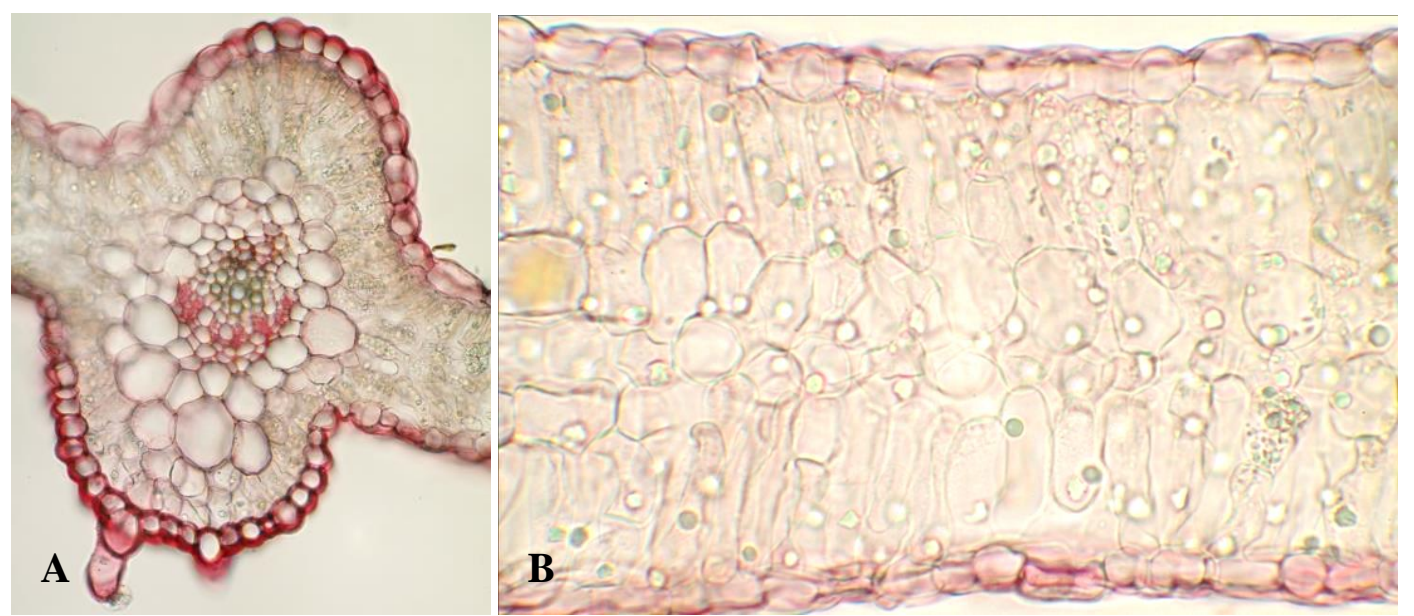

Fig. 5. Artemisia annua leaf: A. Detail of the midrib (40x); B. Detail of the mesophyll (40x) (Photos: Erzsébet Domokos)

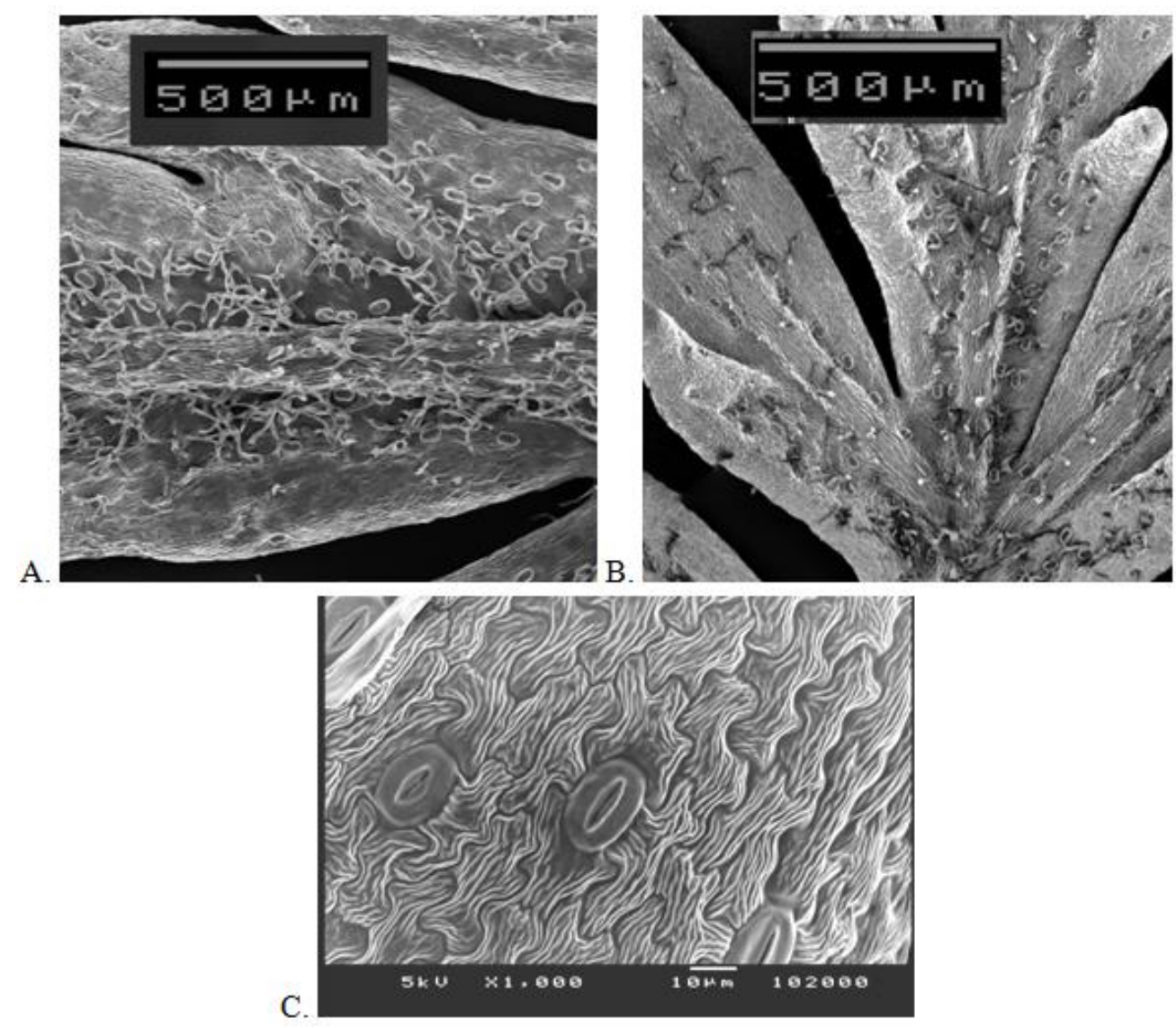

Fig. 6. Upper epidermis of Artemisia annua leafs (SEM, JEOL JSM-5200): A. Glandular hairs of plant treated with Rhizophagus irregularis; B. Glandular hairs of control plant; C. Epidermal cells with sinuately curved anticlinal wall and stomata (Photos: László Jakab-Farkas) 
The measured and compared microscopic characteristics of the vegetative organs in case of treated and control plants were introduced in Table 1. In the roots of treated plants the secondary xylem occupied a significantly larger area than in control plants, while the sclerenchyma tissue occupied a smaller surface in treated plants root (Fig. 1). Zheng et al. (2005) found changes in the activity of enzymes responsible for cell lignification in roots of Capsicum annum plants inoculated with Rhizophagus irregularis. The fungi alleviated the activation of these enzymes (peroxidase-POD, polyphenol oxidase-PPO and phenylalanine ammonia-lyase-PAL) and acted themselves as protection agents against Phytophthora capsici. These findings could explain the lower percentage of lignified cells in roots of treated Artemisia plants.

In case of stem, plants inoculated with fungi had a higher percentage for vascular bundles than control plants, although the number of bundles didn't differ significantly (Fig. 3.).

According to Adolfsson et al. (2015) the inoculated (with Rhizophagus irregularis) Medicago truncatula plants presented significantly larger and thicker leafs than control plants. The number of palisade cells and chloroplasts were also significantly higher for treated plants as compared to controls, although the photosynthetic activity/leaf area was not influenced by the treatment. In our study no differences in leaf thickness were observed, but the area occupied by the palisade parenchyma was larger in case of the treated plants. Mycorrhized plants presented also a significantly higher glandular hair density on the upper epidermis than control plants (as published before in Domokos et al., 2018) (Fig. 6.). This is in accordance with other studies on Artemisia annua inoculated with different arbuscular micorrhyzal fungi (Kapoor et al., 2007; Mandal et al., 2015; Giri, 2017).

Table 1. The microscopic characteristics of vegetative organs in case of mycorrhized and control Artemisia annua plants

\begin{tabular}{|c|c|c|c|}
\hline Vegetative organs & Microscopic characteristics & $\begin{array}{l}\text { Treated plants } \\
(\text { mean } \pm \text { SD })\end{array}$ & $\begin{array}{l}\text { Control plants } \\
(\text { mean } \pm \text { SD })\end{array}$ \\
\hline \multirow{4}{*}{ Root } & & $\mathrm{N}=20$ & $\mathrm{~N}=20$ \\
\hline & Secondary xylem area (\%) & $\begin{array}{l}44.374 \pm 8.022 \\
z=3.509\end{array}$ & $\begin{array}{l}37.169 \pm 7.627 \\
p<\mathbf{0 . 0 0 0 1}\end{array}$ \\
\hline & Sclerenchyma area $(\%)$ & $\begin{array}{l}1.809 \pm 1.071 \\
z=3.397\end{array}$ & $\begin{array}{l}3.264 \pm 0.802 \\
p<\mathbf{0 . 0 0 0 1}\end{array}$ \\
\hline & Number of secretory ducts & $\begin{array}{l}7.100 \pm 3.905 \\
z=1.366\end{array}$ & $\begin{array}{l}8.900 \pm 3.160 \\
p=0.177\end{array}$ \\
\hline \multirow[t]{3}{*}{ Stem } & Vascular bundles area $(\%)$ & $\begin{array}{l}20.380 \pm 3.849 \\
z=2.165\end{array}$ & $\begin{array}{l}18.796 \pm 4.252 \\
\boldsymbol{p}=\mathbf{0 . 0 2 9}\end{array}$ \\
\hline & Sclerenchyma cap area $(\%)$ & $\begin{array}{l}5.768 \pm 1.991 \\
z=1.307\end{array}$ & $\begin{array}{l}5.094 \pm 1.241 \\
p=0.202\end{array}$ \\
\hline & Number of vascular bundles & $\begin{array}{l}11.000 \pm 1.279 \\
z=1.839\end{array}$ & $\begin{array}{l}11.917 \pm 1.831 \\
p=0.076\end{array}$ \\
\hline \multirow[t]{4}{*}{ Leaf } & Palisade parenchyma area $(\%)$ & $\begin{array}{l}39.336 \pm 10.253 \\
z=2.128\end{array}$ & $\begin{array}{l}33.881 \pm 7.973 \\
p=\mathbf{0 . 0 3 2}\end{array}$ \\
\hline & Leaf lamina thickness $(\mathrm{mm})$ & $\begin{array}{l}0.327 \pm 0.045 \\
z=0.858\end{array}$ & $\begin{array}{l}0.352 \pm 0.069 \\
p=0.403\end{array}$ \\
\hline & & $\mathrm{N}=40$ & $\mathrm{~N}=40$ \\
\hline & Glandular hair density $/ \mathrm{mm}^{2}$ & $\begin{array}{l}32.640 \pm 11.130 \\
z=4.234\end{array}$ & $\begin{array}{l}21.769 \pm 7.897 \\
p<\mathbf{0 . 0 0 0 1}\end{array}$ \\
\hline
\end{tabular}

Note: bold values mean significant differences, where $p<0.05$ (Wilcoxon signed rank test) 


\section{Conclusions}

Rhizophagus irregularis can influence the development of vascular tissues in root and stem of Artemisia plants by increasing their surface in the organs. Mycorrhization also reduces the percentage of lignification in the cortex of the root, increases the percentage of palisade parenchyma in leaf and has a positive effect on foliar glandular hair density. Results of this experiment (published earlier) showed also that $R$. irregularis had a positive effect on the biomasses of roots and herba. Further

\section{References}

1. Adolfsson L, Solymosi K, Andersson MX, Keresztes Á, Uddling J, Schoefs B, et al. (2015) Mycorrhiza Symbiosis Increases the Surface for Sunlight Capture in Medicago truncatula for Better Photosynthetic Production. PLoS ONE 10(1): e0115314. doi:10.1371/journal.pone.0115314

2. Chaudhary L V, Kapoor R, Bhatnagar K A (2008) Effectiveness of two arbuscular mycorrhizal fungi on concentrations of essential oil and artemisinin in three accessions of Artemisia annua L. Appl. Soil Ecol. 40, 174-181. doi: 10.1016/j.apsoil.2008.04.003

3. Domokos E, Jakab-Farkas L, Darkó B, Bíró-Janka B, Mara Gy, Albert Cs, Balog A (2018) Increase in Artemisia annua plant biomass content and guaiacol peroxidase activity using the arbuscular mycorrhizal fungus Rhizophagus irregularis. Front Plant Sci. 9:478. doi: 10.3389/fpls.2018.00478

4. Fortin S, Melchert V (2015) Effect of mycorrhizae on Artemisia annua. Worcester Polytechnic Institute.

5. Giri B (2017) Mycorrhizal fungus Rhizophagus fasciculatus promotes artemisinin accumulation in Artemisia annua. In Paper Presented at the Tropentag, investigations are necessary to find out the role of these histo-anatomic alterations in the growth and development of Artemisia plants.

\section{Conflict of Interest}

The authors declare that the research was conducted in the absence of any commercial or financial relationships that could be construed as a potential conflict of interest.

Future Agriculture: Socio-Ecological Transitions and Bio-Cultural Shifts, Bonn.

6. Hammer $\varnothing$, Harper D A T, Ryan P D (2001). PAST: Paleontological statistics software package for education and data analysis. Palaeontologia Electronica 4(1): 9pp. http://palaeo-electronica.org/2001_ 1/past/issue1_01.htm

7. Huang $\mathbf{J} \mathrm{H}$, Tan $\mathbf{J} \mathrm{F}$, Jie $\mathrm{H} \mathrm{K}$, Zeng R S (2011) Effects of inoculating arbuscular mycorrhizal fungi on Artemisia annua growth and its officinal components. Yingyong Shengtai Xuebao, 22(6):14431449.

8. Ivănescu B, Miron A, Lungu C (2015) Histo-anatomy of vegetative organs of some Artemisia species. The MedicalSurgical Journal 119(3):917-924.

9. Kapoor R, Chaudhary V, Bhatnagar AK (2007) Effects of arbuscular mycorrhiza and phosphorus application on artemisinin concentration in Artemisia annua L. Mycorrhiza 17:581-587. doi: 10.1007/s00572-007-0135-4

10. Mandal S, Upadhyay S, Wajid S, Ram M, Jain D C, Singh V P, Abdin M Z, Kapoor R (2015) Arbuscular mycorrhiza increase artemisinin accumulation in Artemisia 
annua by higher expression of key biosynthesis genes via enhanced jasmonic acid levels. Mycorrhiza. 25(5):345-57. doi: 10.1007/s00572-014-0614-3

11. Rapparini F, Llusia J, Penuelas J (2008) Effect of arbuscular mycorrhizal (AM) colonization on terpene emission and content of Artemisia annua L. Plant Biol 10:108-122. doi: 10.1055/s-2007-964963

12. Tan W D, Shen M J, Qiu H J, Zeng F L, Huang J H, Huang R S, Luo W G, Liu Y X (2013) Effects of different phosphorus treatments on Arbuscular mycorrhizal formation, growth and artemisinin content of Artemisia annua. Journal of Southern Agriculture 44(8):1303-1307.

13. Tanase C, Silvia O, Domokos E (2017) Botanică farmaceutică-Îndrumător de lucrări practice, Vol. 3. University Press, Târgu Mureș

14. Tu Y (2017) From Artemisia annua L. to artemisinins: the discovery and developement of artemisinins and antimalarial agents, Academic Press, Cambridge

15. Zheng $\mathrm{H}$ Z, Cui C L, Zhang Y T, Wang D, Jing Y, Kim K Y (2005) Active changes of lignification-related enzymes in pepper response to Glomus intraradices and/or Phytophthora capsici. J Zhejiang Univ Sci B. 6(8):778-86. 